\title{
腰部脊髄疾患におけるミエログラムとサーモグラムの対比
}

東京大学医学部医用電子研究施設臨床部門
本 村 喜代二・・満 㴊 邦 彦
米 沢 卓 実・藤 正
渥 美 和 彦

\section{Comparative Study of Thermographic Findings with Myelographic Findings in the Lumber Disc Disorders}

by

\author{
Kiyoji Motomura, Kunihiko Mabuchi, Takumi Yonezawa, \\ Iwao Fujimasa and Kazuhiko Atsumi \\ Institute of Medical Electronics, \\ Faculty of Medicine University of Tokyo,Tokyo.
}

\begin{abstract}
The purpose of this study is to explore the usefulness of thermography in lumber disc disorders. Preliminary studies indicate that thermography is an excellent procedure for demonstrating the presence and location of root compression. 91 patients with symptoms and signs suggesting root compression received thermography and followed by myelography.

Thermographic findings were compared to myelographic findings and 68 patients were available for this study. Imvolvement of $\mathrm{L}_{4}$ root is characterized by the cold area of antero-lateral thigh, $\mathrm{L}_{5}$ root compression is associated with the cold area of the knee and anterior leg, and $\mathrm{S}_{1}$ root compression is indicated by the cold area of anterior leg, calf and foot. These temperature changes of the lower extremity seem to correspond to myotomes. Thermography was found to be accurate in predicting disc-herniation in $85 \%$ of this series. Peripheral manifestations of cold area is considered to be related with the compression of sympathetic nerves, particularly vasomotor systems.

Thermography which is the pictorial representation of temperature variations can serve to screen patients suffering from root compression syndrome, especially at the $L_{4}, L_{5}$, and $S_{1}$ levels.
\end{abstract}

\section{1.はじめに}

サーモグラフィーとは, 人体の体表面温度分布図の 事であり,医療応用されるようになて 20 年を経ようと している. 頭初の乳癌, 甲状線癌などの表在腫瘍に対 するコンタクトサーモグラフィーの時代から, 現在は, 体表面より放射される赤外線を検知する赤外線サーモ グラフィーを用いて血管系, 神経系疾患に巾広く臨床 応用されている. 非接触型, 易操作性, 情報の客観処 理化など，外来でのスクリーニングに使用できるよう になった. 当教室では, サーモ画像をすべて, パソコ ン処理する事で, 客観的評価を可能としており, 今回
は整形外科領域での応用の一面として, 腰部脊髄疾患, とくに神経根圧迫症候群に対する下肢末梢での，サー モ画像の変化について報告する。

\section{2. 材料および方法}

サーモグラフィー装置は, 富士通インフラアイ 150 ま たは 160 を使用し,画像はすべて PC9801 のディスクに 取り込み，コンピュータ処理を行った．症例は，臨床 上椎間板ヘルニアないしは神経根刺激症状が発現して いる者を，まずサーモグラフィー計測し，そのうち手 術適応者扔よび除外診断上必要とされた症例に対して, アミパークかイソビストによるミエログラムを施行し 
た.こうしてサーモおよびミエロの双方を計測できた 91 症例を分析した。

\section{3. 結 果}

表 1 -（a）は，臨床的に疑われる責任高位別にサー モ所見，ミエロ所見の各々の出現数を単純に比較した 表である。これによると, 各責任高位に対するミエロ/ サーモの陽性率は $\mathrm{L}_{3 / 4}$ で, $90.9 \% / 90.9 \% ， \mathrm{~L}_{4 / 5}$ では $80.9 \% / 95.7 \%, L_{5}$ S では $80.0 \% / 96.0 \%$ ，いづれ もサーモ所見の陽性率が高率であった。表 1 -（b ) は， サーモ所見の有無とミエロ所見の有無を分析したもの であるが，サーモ・ミエロ双方に異常所見が出現した 例が 68/91(74.7\%)，双方共無所見の例が 10/91(11.0 \%)，双所見に不一致の生じた例が 13/91 (14.3\%) で

表 1 - $\mathbf{a}$ 臨床症状とサーモ, ミエロ所見の一致率

\begin{tabular}{c|c|c|c}
\hline \hline $\begin{array}{c}\text { 臨床症状から推定 } \\
\text { される責任高位 }\end{array}$ & 総 数 & ミエロ陽性 & サーモ陽性 \\
\hline $\mathrm{L}_{3 / 4}$ & 11 & 10 & 10 \\
\hline $\mathrm{L}_{4 / 5}$ & 47 & 38 & 45 \\
\hline $\mathrm{L}_{5} \mathrm{~S}$ & 25 & 20 & 24 \\
\hline $\mathrm{LSCS}$ & 8 & 6 & 7 \\
\hline
\end{tabular}

表 1 -b サーモ所見とミエロ所見の対比

\begin{tabular}{c|c|c}
\hline \hline & サーモ(十) & サーモ (-) \\
\hline ミエロ (+) & 68 & 1 \\
\hline ミエロ (-) & 12 & 10 \\
\hline
\end{tabular}

あった。

さらに過去 4 年間の症例分析から得られた, 責任高 位に特異的なサーモパターン（異常所見が出現する率 の高い領域)を分析した結果, $\mathrm{L}_{3 / 4}$ では, 図 1 のごとく 大腿前・外側に冷温域が出現し， $\mathrm{L}_{4 / 5}$ では，図 2 のごと く大腿末梢・膝および下腿前面に冷温域が出現し, $\mathrm{L}_{5} /$ $\mathrm{S}$ では図 3 のごとく下腿全域および足背に高率に異常所 見が出現する事が判明した。これを，責任高位に対応 するサーモ特異パターンとして，ミエロ上確認された 責任高位に対するサーモパターンの一致率で判断する と表 1 - (a ) のごとく $\mathrm{L}_{3 / 4}$ では $90 \%, \mathrm{~L}_{4 / 5}$ では 84.2 \%, $\mathrm{L}_{5} / \mathrm{S}$ では 85 \%となり，サーモパターンのみから 責任高位の推定が可能である事が示唆された。ただし， $\mathrm{L}_{2 / 3}$ では下肢末梢での特異パターンは乏しく, LSCS て は，年令的に動脈硬化など，血管系疾患の因子が影響 してくる為, サーモパターンのみから, LSCS の範囲を 求める事は，困難であった。

\section{4. 考察}

サーモグラフィー上，特種なケースを除いて一般的

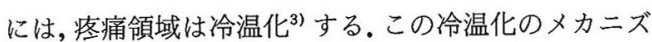
表 1 -c ミエロ所見とサーモパターンの一致率

\begin{tabular}{c|c|c|c}
\hline \hline & $\begin{array}{c}\text { ミエロ上の } \\
\text { 圧迫例 数 }\end{array}$ & \multicolumn{2}{|c|}{$\begin{array}{c}\text { サー゚ターン 例 数 } \\
\text { 致 率 }\end{array}$} \\
\hline $\mathrm{L}_{3 / 4}$ & 10 & 9 & $90 \%$ \\
\hline $\mathrm{L}_{4 / 5}$ & 38 & 32 & $84.2 \%$ \\
\hline $\mathrm{L}_{5} \mathrm{~S}$ & 20 & 17 & $85.0 \%$ \\
\hline
\end{tabular}
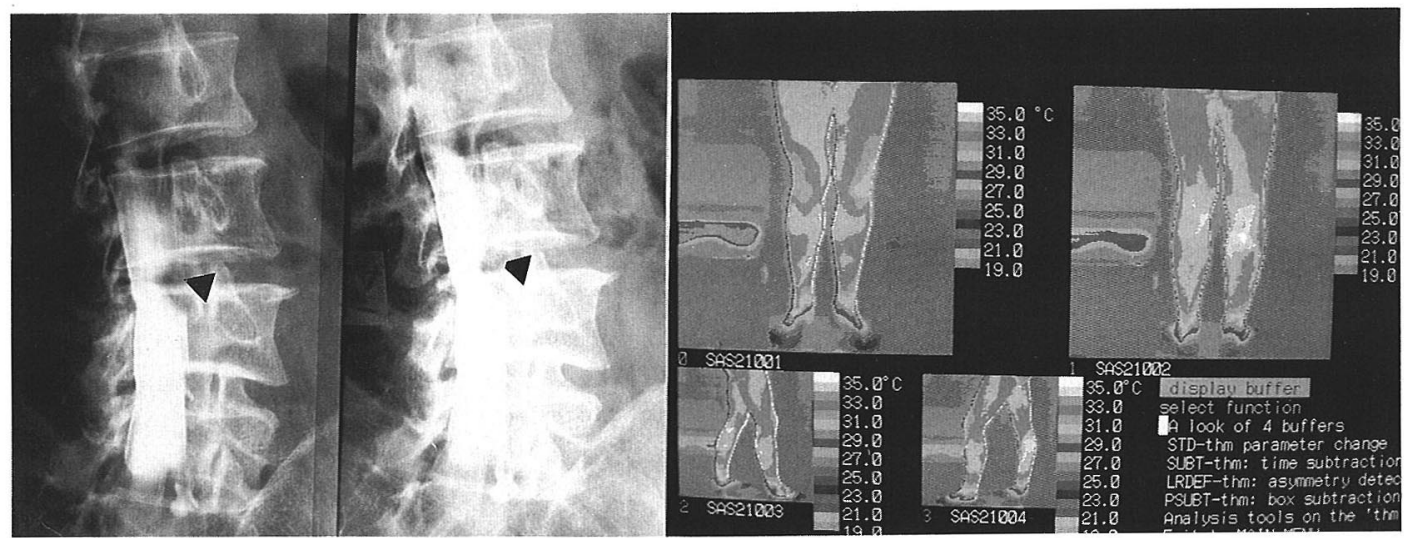

図 $1 \mathrm{~L}_{3 / 4}$ のヘルニアのミエロ像とサーモ画像：左大腿部に冷温域が出現し下腿での左右差はみられない.臨床的には, 左股関節部から大腿外側での疼痛および軽度の知覚低下を認めた。 


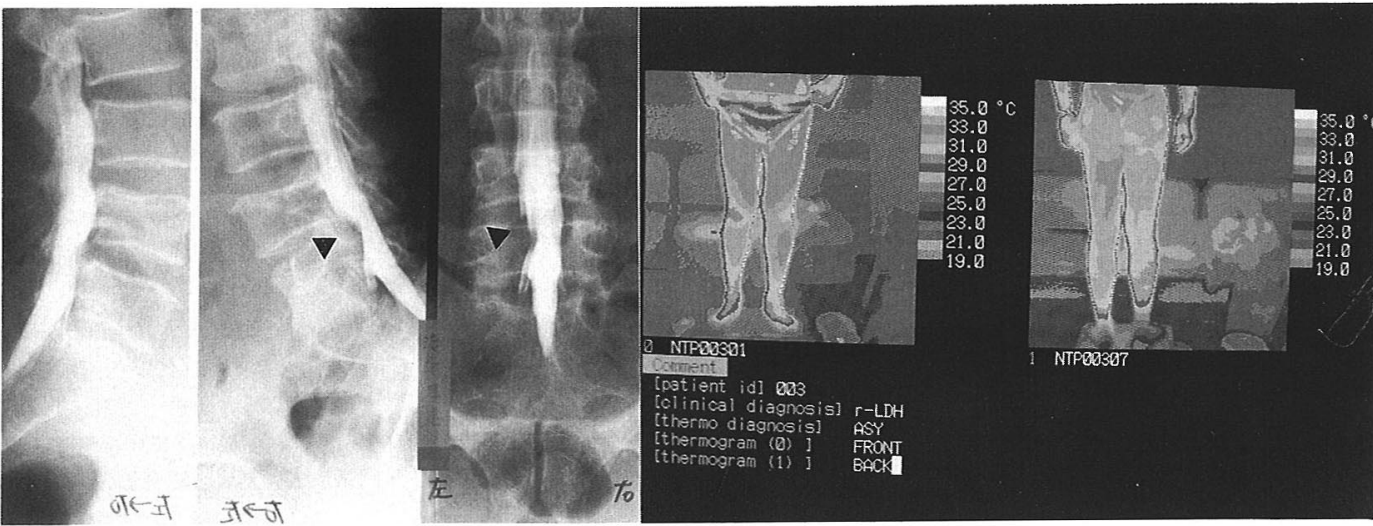

図 $2 \mathrm{~L}_{4 / 5}$ でのヘルニアを示すミエロ像とサーモ画像. 右膝周囲から下腿にかけて冷温域を認める.臨床的には強度の 腰痛と下酿外側への放散痛, シビレを主訴とした。
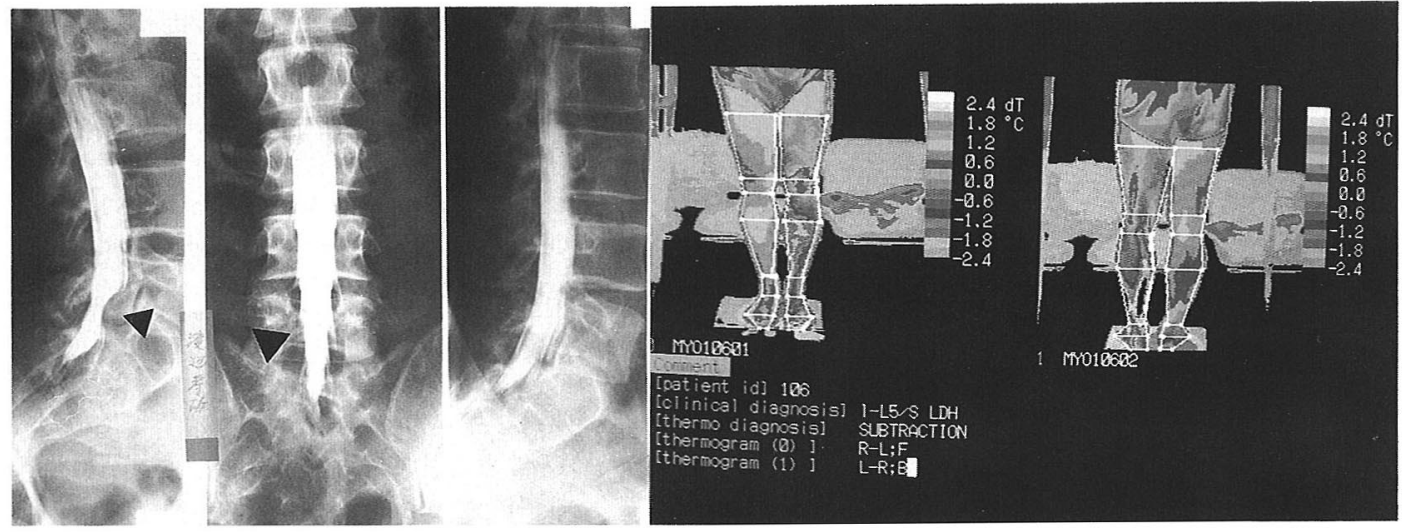

図 $3 \mathrm{~L}_{5} / \mathrm{S}$ のヘニアのミエロ像と, 左右差減算サーモグラフィー図. 減算像に扔いて, 左下腿内側, 腓腹部, 足部 に著しい左右差が認められ，臨床的な疼痛，シビレの主訴と分布が一致していた。

ムは色々と考えられるが, 一番重要な因子は, 疼痛に 伴って惹起される筋肉収縮によって，二次的におこる 局所血流減少，阻血性変化である。阻血により好気性 代謝の不活化, 熱産性の減少と共に, 発痛物質の蓄積 など，悪循環が成立する。長期慢性化すると，筋肉萎 縮をきたし熱放散も増加する。椎間板へルニアに代表 される root compression syndrome では, 圧迫の存在 する腰部局所での異常温度分布よりも, 神経伝導系路 の末梢における異常が，サーモグラム上は観察されや すい. 文献上, サーモとミエロの対比による局在診断 率を比較すると，いずれも腰部の温度変化に主眼をお き，下肢温度変化に対する検討が不十分である。サー モグラムによる腰部椎間板へルニアの局在診断率は
Edeiken $^{1)} 23 / 29$ (79\%), Raskin ${ }^{6)} 27 / 24$ (70\%), Pochaczevsky ${ }^{5)} 35 / 38$ (95\%)，相井 ${ }^{7)} 12 / 22$ (54.5\%) であるが，われわれの例では 58/68（85.3\%）であっ た。前述したごとく, $\mathrm{L}_{3 / 4}$ レベルでは, 大腿末梢前, 外 側に冷温域が出現し, $\mathrm{L}_{4 / 5}$ では, 膝周囲から下腿, $\mathrm{L}_{5} /$ $\mathrm{S}$ では, 下腿全域および足部に特異的冷温分布を観察で きるが，これらは汎用されているダーマトームには一 致しない. $\mathrm{L}_{3 / 4}$ レベルでの冷温域は, 大腿直筋・外側広 筋 $\left(\mathrm{L}_{2}-\mathrm{L}_{4}\right)$ に, $\mathrm{L}_{4 / 5}$ での冷温域は主に前脛骨筋 $\left(\mathrm{L}_{4}\right.$, $\left.\mathrm{L}_{5}\right)$ に一致し, $\mathrm{L}_{5} / \mathrm{S}$ では長趾伸筋 $\left(\mathrm{L}_{5} / \mathrm{S}\right)$, 下腿三頭 筋（S）に一致することから, サーモ上の冷温域はミ ヨトームに一致すると理解できるのが無理がない。こ の所見は腰部疾患に限らず,われわれ4) が以前報告した 
ごとく頸部の root compression でも同様である.した がってサーモ画像を解釈する際は，ダーマトームにこ だわっては局在診断に無理が生ずる、サーモ画像の解 釈・処理にあたっては正常人のパターンを熟知する必 要があるが, 原則的には, 左右差は $0.4^{\circ} \mathrm{C}$ 以内, 肥満 とやせ型の有意差はなく，女性が男性よりやや高温で ある．季節によって体表温は変動するので単なる絶対 温度の比較は意味がなく, 左右差を検出することが最 も重要となる．当教室ではその目的で左右差減算サー モグラフィー (both-side subtraction), 経時的な温度 変化をみる時間差サーモグラフィー（time subtraction), 単位重量あたりの血流を表示する処理系など, 臨床的に有用な客観処理法を開発している。サーモ画 像は, 構造的変化を視覚化するものではなく, 生理機 能の一面を，赤外線という波長を介して視覚化したも のであるからその解粕はきわめて複雑である．椎間板 ヘルニアなどによる root compression syndrome では, 神経根からでてくる交感神経2), とくに vasomotor system との関与が, 重要な因子をなすものと推測される. とくに，この部位では，交感神経は節後繊維として存 在し, 無髄であることから, 運動·感覚神経に比べて, 圧迫刺激に弱いことが考えられる，したがってひきお こされた vasomotor の緊張は, 当該領域の血管系収縮 をおこし，結果的に皮膚・筋血流低下を誘発すると考 えられる.サーモグラフィーは, 異質の生理機能情報 をわれわれに提供してくれると共に，整形外科領域で はその利点をもっとも享受できる分野であると考えら れ, 診断的応用価值はきわめて高いと判断される.

\section{5. まと め}

1. サーモグラフィー，ミエログラフィー双方で異 常所見を呈した 68 例の腰部椎間板へルニアについて分 析・検討した。

2. サーモグラムによる局在診断率は $\mathrm{L}_{3 / 4}$ で $90 \%$, $\mathrm{L}_{4 / 5}$ で $84.2 \%, \mathrm{~L}_{5} / \mathrm{S}$ で $85.0 \%$ ，全体で $85.3 \%$ と高 率であった。

3. 腰部のサーモ所見より下肢末梢での温度変化が 診断上有用であった。すなわち $L_{3 / 4}$ では, 大胀外側・ 前面に, $\mathrm{L}_{4 / 5}$ では膝周囲および下腿前面に, $\mathrm{L}_{5} / \mathrm{S}$ では 下腿全面・足部に特異的冷温域を観察できた。
4.この冷温域は, ダーマトームとは一致せずむし ろミヨトームに一致すると判断された。

5. 椎間板ヘルニアにおける末梢での冷温化には root compression による交感神経障害が関与している と推測された。

\section{参 考 文 献}

1) Edeiken, J. and Wallace, J. D.: Thermography and herniated lumbar discs. A. J. R. 162: 4, 790-796, 1968.

2）满㴊邦彦，本村喜代二，藤 正厳，渥美和彦：サーモ グラフィーによる神経障害部位診断。総合臨床, $36: 9$, 1911-1915， 1987.

3）本村喜代二, 満渕邦彦, 藤 正厳, 渥美和彦：頸部整 形外科疾患におけるサーモグラフィーの応用。西日本整 災誌，34:1，276-280, 1985。

4）本村喜代二, 満㴊邦彦, 藤 正厳, 渥美和彦: 整形外 科領域疾患でのサーモグラフィーの応用. Biomedical Thermography. 6:2, 189-193, 1986.

5) Pochaczevsky, R. and Wexler, C. E. : Liquid crys tal thermography of the spine and extremities. J. Neurosurg. 56: 386-395, 1982.

6) Raskin, M. M. and Martinez-Lopez, M.: Lumbar thermography in discogenic disease. Radiology. 119: 149-152, 1976.

7）相井平八郎, 小山素麿：春椎・脊髄疾患のサーモグラ フィー。臨床放射線，28：457-461，1983。
質 問 山口大学 貴船 雅夫
(1) 有意な皮膚温低下は何度からか.
(2) 両側性の障害がある時の皮膚温低下に対しては どのように考えているか.

\section{解 答東京大学 本村喜代二}

(1) $0.4^{\circ} \mathrm{C}$ 以上の差は有意差と一般的にはいわれてい ます。ただし，利き腕や異常に片側が鍛練されている 場合は別です。私達は $1^{\circ} \mathrm{C}$. 以上の差は絶対的に異常差 と判断しています。

(2) サーモグラムは左右差の判断がもっとも重要て あり，そういう点から，両側性の障害には本法はあま り適していないと考えています。

健側をコントロールとして，患側との差が最も有用 な情報となりうるわけですから，片側性神経根障害が もっとも適した疾患と判断されます。 